\title{
From Endothelial Progenitor Cells to Tissue Engineering: How Far have we Come?
}

Barbara Salingova, Martina Madarasova, Stanislav Stejskal, Lenka Tesarova, Pavel Simara and Irena Koutna*

Centre for Biomedical Image Analysis, Faculty of Informatics, Masaryk University, 60200 Brno; Czech Republic

\begin{abstract}
Cardiovascular disease has become the leading cause of death in high income countries worldwide and the available treatment is not able to provide a complete recovery. Tissue engineering offers a possibility to construct autologous vein replacements for surgery. In this review we summarize approaches leading to artificial vascular graft construction. We discuss biomaterials currently in use, various drug delivery systems and the most appropriate cell cultures for vein engineering. Despite the progress in biomaterials and drug delivery systems, generating a suitable tissue microenvironment and selection of the appropriate cell population for graft seeding remains a major challenge. Here we focus on endothelial progenitor stem cells as the most suitable cell type for vascular graft construction. We discuss its sources, isolation techniques and differentiation procedures.
\end{abstract}

\section{Keywords: EPC; In vitro vascularization; Small-diameter vessels}

\section{Introduction}

Cardiovascular disease has become one of the most significant civilization health problems in the population of high income countries [1]. Modern medicine focuses on symptom treatment that is financially demanding and does not offer a permanent solution. In contrast tissue engineering and regenerative medicine offer a way to treat the underlined problem and achieve complete recovery [2-4]. New approaches in artificial vessel formation could significantly affect the therapy of ischemic injury, treatment of cardiovascular diseases and tissue engineering research. Tissue engineering is dependent on the ability to supply the tissue with nutrients and being able to dispose of the waste products. Vascularization is therefore an essential process in construction of any functional organ. In this context endothelial differentiation is becoming more and more attractive issue.

Human veins consist of multiple layers, each responsible for multiple functions within this complex system. The inner layer of endothelial cells forms a dynamic physiological barrier between circulating blood and the surrounding tissue. It protects the inner surface of the vein and regulates multiple physiological processes involving vessel repair, transport, coagulation and immune response [5]. It was believed that after embryonic development the repair and formation of new vessels occurred mostly through angiogenesis [5,6]. Angiogenesis is a process where postnatal vessel formation is perpetuated strictly by proliferation and migration of the neighbouring endothelial cells. However, this dogma was challenged when Asahara presented a new concept of postnatal vessel formation; postnatal vasculogenesis $[7,8]$. He isolated a bone marrow cell population that contributed to new endothelial formation and named them Endothelial Progenitor Cells (EPCs). This discovery changed the traditional understanding of vessel formation and proved that endothelial progenitors present in bone marrow do participate in vessel repair, and are able to form new vessels in vivo through process similar to embryonic vasculogenesis.

Multipotent stem/progenitor cells exist in nearly every organ of the human body $[9,10]$. They possess high proliferation activity and the ability to produce differentiated cell population in order to restore tissue homoeostasis. For example bone marrow is a source of various progenitor/stem cells including Hematopoietic Stem Cells (HSCs), Mesenchymal Stem Cells (MSCs) and EPCs [11,12]. These cells are isolated from bone marrow as a mixed cell population obscuring their origin and identity [13-16].

The EPCs play a major role in neovascularization $[17,18]$. The delivery of EPCs by injection or bioengineered vascular grafts resulted in enhanced angiogenesis in models of ischemia or infarction [19-21]. Despite the unresolved issues concerning the origin and differentiation mechanism of EPCs, their clinical application has encountered significant success in tissue engineering of large-diameter vessels, therapy of ischemic limb, and aneurysm and pulmonary arterial hypertension [22-26]. EPCs have also been investigated as a potential biomarker primarily for cardiovascular, but also several other diseases $[27,28]$.

\section{Origin of EPCs}

EPCs are present all over the human body including in bone marrow, cord blood, spleen, the liver, intestinal and vessel walls, and blood stream circulation. They also show stemness and are able to differentiate into endothelial cells $[29,30]$. However, these properties were not shown to correspond with a unique surface expression pattern or easily detectable function $[31,32]$. The EPCs are isolated from bone marrow as a mixed cell population along with other cell populations with stem cell characteristics. Many of the surface characteristics are shared among various hematopoietic and endothelial precursor cell populations in different stages of differentiation, which obscures the origin and identity of EPCs. Furthermore, considering the plasticity of the stem cell phenotype, one or another particular marker cannot possibly define a distinct progenitor cell population. Table 1 offers an overview of various populations that produce EPCs and their

*Corresponding author: Irena Koutna, Centre for Biomedical Image Analysis,FI, Masaryk University, Botanická 68a, 60200 Brno, Czech Republic, Tel: 420549493969; Fax: 420549498360; E-mail: qkoutna@fi.muni.cz

Received February 12, 2014; Accepted March 24, 2014; Published March 26 , 2014

Citation: Salingova B, Madarasova M, Stejskal S, Tesarova L, Simara P, et al. (2014) From Endothelial Progenitor Cells to Tissue Engineering: How Far have we Come? J Stem Cell Res Ther 4: 185. doi:10.4172/2157-7633.1000185

Copyright: (c) 2014 Salingova B, et al. This is an open-access article distributed under the terms of the Creative Commons Attribution License, which permits unrestricted use, distribution, and reproduction in any medium, provided the original author and source are credited. 
surface markers used for isolation [8,32-46]. According to their growth patterns, we can distinguish early and late outgrowth EPCs in the in vitro cell culture. All of the mentioned factors account for both the lack of standardized criteria and cell surface markers used for characterization and isolation [47].

\section{Mobilization of EPCs}

One of the major disputed issues in EPC research is the incidence of EPCs in various tissues $[29,31]$. These cells are generally isolated from three major sources - umbilical blood, bone marrow and circulating blood $[33,48,49]$. Although several authors reported the isolation of CD34+ cells from peripheral blood, the cell population is too small for any major applications $[41,50]$. Tissue engineering approaches used mixed populations of endothelial and mesodermal cells for their applications. However several studies require relatively large numbers of EPCs. Mobilization of EPCs into peripheral blood is a relatively noninvasive procedure that provides the required quantity of EPCs [48].

In physiological conditions, the EPCs are largely restricted to bone marrow. EPCs incidence in peripheral blood remains low and relates to the state of the vascular system and lifestyle. Factors able to influence the EPC count include smoking, obesity and exercise [51-54]. Endogenous mobilization of bone marrow EPCs is a consequence of several pathological processes including ischemic injury, tissue trauma, wound healing, or tumor growth [55,56]. Induced mobilization of bone marrow stem cells into the blood stream increases EPC counts in peripheral blood and is a desired effect prior to isolation. Table 2 summarizes various endo and exogenous factors inducing mobilization of EPCs [57-71].
Bone marrow stem cell mobilization into peripheral blood is dependent on the local microenvironment consisting of fibroblasts, osteoblasts and endothelial cells. Mobilization occurs after the concentration of cytokines in blood exceeds the levels in bone marrow. They activate endothelial nitric oxide synthase and nitric oxide production, which leads to activation of metalloproteinases (MMPs) [55,72]. MMPs have the ability to release EPCs from bone marrow into peripheral blood $[65,73]$.

\section{Detection of EPCs}

In several pathological situations EPCs can be used as a potent biomarker for determination of the cardiovascular condition of the patient $[28,74]$. Clinical studies focused on the evaluation of disease conditions including cardiomyopathy, ischemia, stroke, coronary artery disease and diabetes on the mobilization and function of EPCs [75-80]. The EPC-based therapy approaches rely on the extent of incorporation of the in situ mobilized cells. However, this process shows a high variability of $1-50 \%$, which can be attributed to the patients genetic variation but also to the lack of standardization in the methodology. Modern isolation procedures make the process more effective and less time-consuming; however diversify the methodology even further [81-83]. Standard techniques for determination of the EPC count include isolation and cultivation, flow cytometry and Stromal cellDerived Factor 1 (SDF-1) assay. Modern isolation procedures make the isolation and cultivation more effective and less time consuming, however that makes the methodology even more diverse $[81,82]$. The standardization of detection and cultivation procedures is therefore essential.

\begin{tabular}{|c|c|c|c|c|}
\hline Origin & Precursor cell population & Surface characteristics & In vitrocell culture & References \\
\hline \multirow{2}{*}{ Bone marrow } & Post-natal hemangioblast & CD14+ & Early outgrowth EPCs & {$[8,42]$} \\
\hline & Myelo/monocytic progenitors & CD34+/VECFR-2+/CD133+ & Late outgrowth EPCs & {$[8,33,35]$} \\
\hline \multirow{2}{*}{ Mobilized peripheral blood } & Post-natal hemangioblast & CD14+ & Early outgrowth EPCs & {$[32,34,41]$} \\
\hline & Myelo/monocytic progenitors & CD34+/VECFR-2+/CD133+ & Late outgrowth EPCs & {$[32,34]$} \\
\hline \multirow{2}{*}{ Adipose tissue } & \multirow{2}{*}{ Adipose-derived stem cells } & CD34+/CD146+ & Early outgrowth EPCs & {$[36,37,38]$} \\
\hline & & CD34+/CD31+/CD133+ & Late outgrowth EPCs & [44-46] \\
\hline \multirow{2}{*}{ Umbilical cord blood } & \multirow{2}{*}{ HSCs/MSCs/EPCs } & CD34+/CD133+ & Late outgrowth EPCs & {$[43,34]$} \\
\hline & & CD14+/CD133- & Early outgrowth EPCs & {$[43,34]$} \\
\hline Blood vessel wall & EPCs/HSCs & CD34+/CD31- & Early outgrowth EPCs & {$[39,40]$} \\
\hline
\end{tabular}

Table 1: Endothelial Progenitor Cell (EPCs) populations, their sources for isolation, surface characteristic and cell populations obtained by in vitro cultivation.

Exogenous mobilization factors:

\section{Cytokines}

\section{Statins}

Growth factors

Pharmacological agents

Endogenous mobilization factors:

\section{Growth factors}

\begin{tabular}{|l|l|}
\hline Statins & Chemokines \\
\hline Cytokines & Sormones \\
\hline Hor
\end{tabular}

Hormones

Table 2: Exogenous and endogenous mobilization factors (Exogenous factors are used for pharmacological induction of mobilization. Endogenous are naturally secreted in human body as a result of pathological conditions.)

\begin{tabular}{|l|}
\hline References \\
\hline$[57]$ \\
{$[58]$} \\
\hline$[59]$ \\
\hline$[60]$ \\
\hline$[61,62]$ \\
\hline$[63]$ \\
\hline$[71]$ \\
\hline References \\
\hline$[61,62]$ \\
\hline$[63]$ \\
\hline$[64]$ \\
\hline$[67,69]$ \\
\hline$[65]$ \\
\hline$[57]$ \\
\hline$[58]$ \\
\hline$[66]$ \\
\hline
\end{tabular}

Granulocyte colony-stimulating factor (G-CSF)

Granulocyte-macrophage colony-stimulating factor (GM-CSF) Rosuvastatin

Simvastatin

Vascular endothelial growth factor (VEGF)

Basic fibroblast growth factor (bFGF)

CXCR4 antagonist

bFGF

VEGF

Erythropoietin

SDF-1

G-CSF (mobilizes CD34+ cells)

GM-CSF (mobilizes EPCs)

Parathyroid hormone 
Three major factors complicate the detection of EPCs (1) the heterogeneity of the EPCs (2) low incidence of CD34+/VEGFR-2 in peripheral blood (3) heterogeneity of the used techniques. The EPCs phenotype is shared among various cell types present in bone marrow or peripheral blood [84]. Therefore using 2-3 surface antigens for identification of a cell population with a complex function is a simplistic concept at best. Low incidence of CD34+, VEGFR-2+ cells in peripheral blood also complicates the analysis of the EPC count. They represent only $0,002 \%$ or $0,02 \%$ of total mononuclear cells isolated from peripheral blood or mobilized peripheral blood respectively $[41,50]$. Evaluation of these extremely rare events presents a problem and can lead to false positive results [31]. Finally, the last of the complicating factors is the heterogeneity of the techniques used for EPC quantification. To determine the EPCs incidence, flow cytometry and cultivation methods are commonly used. EPC cultivation methods do not take into account the fact that the final number of colonies obtained after the process does not correspond to the quantity of initially plated EPCs [31,85]. It is dependent on a complex set of processes involving adhesion, proliferation and differentiation of original cell. This heterogeneity complicates the comparison of the obtained data and results in misleading conclusions.

The quickest and most efficient method for determination the EPC count is detection by flow cytometry after marking. The greatest advantage is the parallel detection of endothelial and stem cell associated markers and the possibility to use analyzed cells for further cultivation. To define the phenotype of EPCs at least two markers should be useda stemness marker to account for the stem cell potential as well as an endothelial marker to identify the endothelial characteristics of the progenitor populations. Most commonly used markers are CD34, CD133, VEGFR-2 [86,87].

An alternative method to determine the EPC count is an indirect quantification using Stromal cell-Derived Factor (SDF-1). It is an inducer of endothelial progenitor cell migration from the bone marrow. The method is based on the inverse correlation of SDF-1 and VEGF levels with EPC incidence. This method could potentially eliminate the inaccuracies caused by isolation, preparation and techniques of detection. It could therefore create a standardized parameter that would be comparable among different studies [88]. However the correlation of SDF-1 level and EPC count is a complex process involving unknown mechanisms that must be further studied before clinical application.

\section{Isolation and Cultivation of EPCs}

In vitro cultivation of EPCs provides two distinct cell populations [34]. They have been designated as early and late outgrowth EPCs with their distinct growth patterns and the ability to secrete angiogenic factors [32,43]. Although they have distinct origins and show functional differences in vitro, both were shown to contribute to in vivo neovascularization in several disease models. Mechanisms of action differ between cell populations and have not yet been precisely described [89-92].

The cultivation on fibronectine coated dishes with pre-plating yields early outgrowth endothelial cell population (eEPCs) [28]. Preplating is a procedure designed to avoid the contamination with earlyadherent cells of mesodermal origin. The colonies start to appear after 4-7 days after re-plating and their numbers peek at 2-3 weeks. They can be maintained up to 4 weeks in vitro. They show a spindleshaped phenotype and the expression surface markers CD14 and CD45 suggests hematopoietic origin. eEPCs do not incorporate into vessel walls. However are able to secrete multiple angiogenic, antiangiogenic and neuroregulatory cytokines and stimulate the process of endothelial formation. Therefore recent studies linked this cell population to primitive hematopoietic cells composed of monocytes and T-cells [93]. Some authors consider the eEPCs a manifestation of the multiple differentiation potential of monocyte/macrophage cell population, which allows them to assume an endothelial-like phenotype under appropriate cultivation conditions $[94,95]$.

On the basis of eEPC cultivation a commercial assay has been developed by Hill and colleagues for the determination of cardiovascular risk $[28,68,96]$. Colonies begin to appear three days after re-plating. Positive eEPC colonies are characterized by specific morphology - round-shaped cells in the core and elongated cells on the periphery. These cells are also characterized by the expression of von Willenbrand factor, VEGFR-2 and CD31. Even though the derived cells do not incorporate into vasculature, this method showed correlation between the frequency of colony formation and cardiovascular risk. Low levels of EPCs in peripheral blood are considered a biomarker for cumulative cardiovascular risk. Easy execution and the ability to accurately characterize endothelial function and predict cardiovascular risk makes the eEPC assay a potent biomarker $[97,98]$.

The second endothelial cell population, designated as late outgrowth cells, appeared after 2-3 weeks of cultivation and was able to be maintained in culture up to 12 weeks [24,34,99]. They showed an endothelial like phenotype, cobbelstone shape and apicobasal polarity. They expressed a complete endothelial phenotype, CD146, CD105 and lacked CD14 surface marker [100]. They have the ability to incorporate into cell walls and form junction-like cell-cell contacts as well as to form capillary tubes in vitro $[32,101,102]$. Therefore, these cells are considered true endothelial precursors and widely used for tissue engineering.

\section{Blood Vessel Engineering}

A promising application of EPC research is the utilization for vascular tissue engineering. Several strategies of vessel construction are nowadays in clinical trials. Even though large vessel transplants achieved encouraging results, clinical trials for small-diameter vessel replacements have encountered only limited success [23,103-106]. The tissue engineering triad consists of (1) scaffold with appropriate mechanical and biological properties (2) time-dependent angiogenenic stimulation (3) cells seeded in vitro or mobilized and guided to the injury site in vivo. Figure 1 explains the mechanism of in vitro engineering of vascular graft.

Scaffolds for tissue engineering must possess the three basic attributes: biodegradability, non-immunogenicity and must structurally substitute the function of the replaced tissue until the cell reconstitution is completed. Up to date several attempts aimed to construct veins and arteries suitable for application in transplantation medicine. First study dates to 1970, when Herring and co-workers seeded EC on polytetrafluoroethylene scaffolds [107-109]. However the used EP isolation method (mechanic scraping of the arterial endothelium) caused high impurity of the seeding material. More successful was the attempt of Weinberg and Bell in 1986 [110]. They constructed a tubular structure formed by collagen, bovine smooth muscle cells and non-degradable artificial material. The lumen was seeded with vascular fibroblasts and EC cells. The graft closely resembled native blood vessels, however did not possess the ability to withstand physiologic pressure bursts.Further research led to improvements in the biomaterials for 


\section{IN VITRO VASCULAR ENGINEERING}

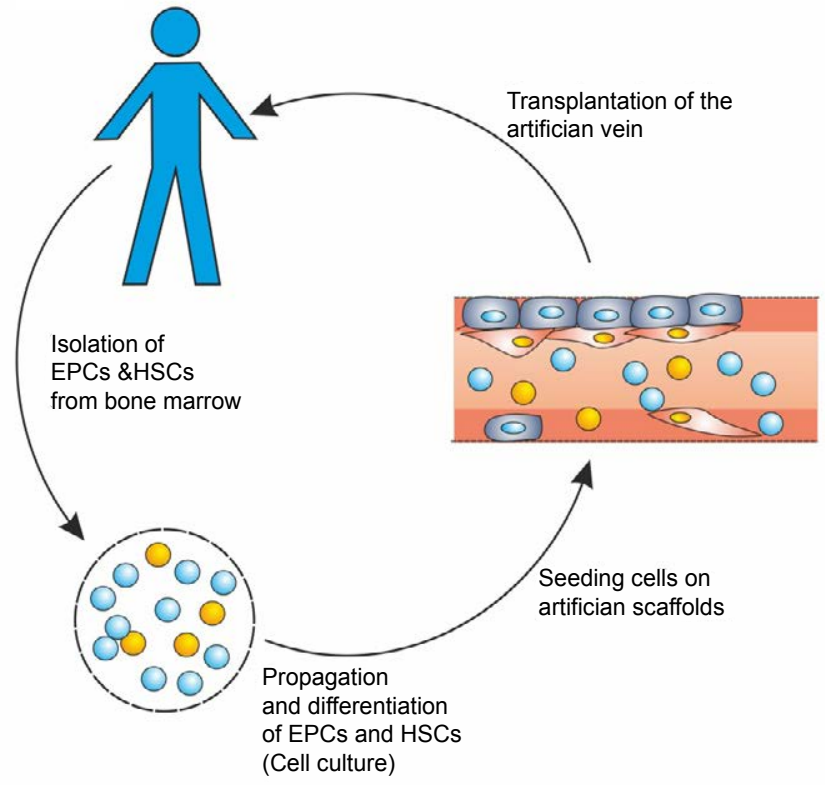

Figure 1: In vitrovascular engineering. EPC are isolated from patients mobilized peripheral blood and cultivated in vitro. Bioengineered scaffolds are seeded with EPCs (or co-cultures of EPCs) and cultivated in bioreactors in cotrolled conditions. Bioengineered graft is transplanted back to the patient.

scaffold construction and modification by extracellular matrix coating to achieve better cell adhesion properties [111]. Today the vascular design of the constructed vein is mechanically sound and satisfactory for clinical application. The blood vessels are able to withstand enormous pressures (above $2000 \mathrm{mmHg}$ ) while retaining their contractible quality [112]. Materials for vascular replacements can be also modified to possess additional qualities to provide the ideal microenvironment for processes connected with vessel repair and for all intents and purposes to resemble the native tissue [113].

Currently, two major approaches are utilized in development of scaffolds for tissue engineering - the use of synthetic materials and organic tissues (decellularised human or animal blood vessels) [114-116]. The most commonly used polymers for construction of biopolymere scaffolds include Polycolicacid (PGA), Polylacticacid (PLA), Polycaprolactone (PCL) and Polyurethane (PU) [117-120]. They differ in their basic characteristics including biodegradability, elasticity and strength. In scaffold construction the ratio of the individual polymer components can be modulated to insure the desired properties and accommodate specific requirements of the transplantation site [121]. The most widely used polymere in preclinical studies is PGA. Artificial polymere scaffolds have hydrophobic surfaces and are therefore further modified with PEG, heparin or albumin to increase hemocompatibility [122].

Engineering of large-diameter vessels successfully utilized biodegradable scaffolds. The bioengineered graft showed long-term patency in mid- and long-term studies [103,123]. The composite polymer consisted of a tube composed of 50:50 ratio of PCL and PLA copolymer and a PGA woven fabric. The scaffold was seeded with autologous bone-derived cells. Twenty-five grafts were implanted into patients born with single ventricle cardiac anomalies [103]. A follow up study of long-term patency (7 years after implantation) showed promising results, when the implanted conduits were functional and none of the patients required additional graft replacement. $40 \%$ of the patients also did not require any medication related to their heart condition. However, $16 \%$ of the patients showed graft stenosis that was successfully treated. Although this pioneer study showed promising results, the mechanisms that lead to failure in small-diameter vascular grafts are still not understood.

In 1998 L'Heureux et al. [124] presented an alternative method of scaffold engineering - self-assembly [124-127]. The vascular graft was constructed without the use of bio-polymere material. This method takes advantage of the natural ability of mesenchymal cells to secrete native ECM. Mesenchymal cells are grown in over confluence producing self-assembled tissue sheets. They are further processed in vitro using a mandrel to form a tubular structure. A prolonged incubation period ensures the circumferential cell arrangement and large amount production of extracellular matrix [23]. These conduits are able to withstand high pressures and are currently under investigation for hemodialysis access grafts in human patients [128-130]. This approach has been successfully used in clinical trials for patients that do not need immediate bypass treatment.

A similar method was used in 2011 by Dahl et al. [131] in the construction of a human vascular graft using SMCs. The decellularized grafts were implanted into baboons [131]. The engineered constructs maintained patency for up to six months. This successful in vivo study was followed by clinical trials in Europe and USA in 2012 and 2013 respectively and is currently in progress [132]. Two major advantages of this approach include (1) acellular human-based grafts do not cause a significant immune response in nonhuman hosts (2) small-diameter vascular grafts show low rates of thrombosis [133]. This method is also currently being investigated for application in the vascularization of ischemic myocardium [134]. Its considerable limitation however lies in donor variability, the ability of the donor SMCs to form ECM in vitro.

Even though various tissue engineering approaches noted promising results in reconstruction of large vessels, they show discouraging performance in small-diameter application [110,135137]. The main reason for these shortcomings is caused by increased thrombocity due to the absence of functional endothelium and the development of initial hyperplasia. Especially in low flow situations, small-diameter veins demonstrate low patency [138-141]. Although multiple efforts are aimed towards the development of new material substitutes and surface modification techniques, they are still not comparable with the performance of native tissues [142-144]. Table 3 contains an overview of pre-clinical studies in vascular engineering in the past years $[70,103,118,131,145-147]$.

\section{Angiogenesis In vitro}

One of the major challenges of tissue engineering lies in the establishment of an environment that closely resembles in vivo conditions. These conditions can either be simulated artificially, where the angiogenic factors, or masterswitch activators are a part of a biodegradable scaffold, or the lack of growth factors can be compensated for by co-cultures [148,149].

The development of recombinant angiogenic and vasculogenic growth factors initiated research into its utilization for bioengineering. A number of growth factors have been tested in clinical trials including VEGF, PDGF, FGF and HGF (hepatic growth factor) [150-153]. Phase I trials reported promising results $[154,155]$. However, the results obtained in phase II did not demonstrate expected benefit to patients 
[156]. These disappointing clinical results could be attributed to the short lived effect or instability of the injected medicament as well as to the multiple issues related to viral infection procedures.

Recombinant proteins or direct administration of medicament provide burst-release dosing. In contrast, bioengineered transplants require a sustained and controlled release of growth factors to facilitate a prolonged treatment. Table 4 shows a list of angiogenic stimulants and their role in vascularization in chronological order [72,157-163]. In contrast to the burst-release dosing, microparticle release mechanisms allow for the time-dependent release of the angiogeneic stimulation. They are constructed from biodegradable materials for example poly (lactic-co-glycolic acid) (PLGA) or acetylated dextran(AcDex) [20,164]. Several different combinations of angiogenic signaling molecule sand delivery systems were studied [165-169]. These studies showed encouraging results, however were not able to achieve the full restoration of function due to the complexity of the healing process.

Perspective 'release-on-demand' platforms represent yet another alternative approach to the delivery systems [170]. They use the principles of enzyme-mediated growth factor release. It is able to provide a time- and location-restricted release of the growth factors. It was shown that regulated delivery of angiogenic and blood vessel maturating factors was able to form functionally mature vessels composed of ECs and smooth muscle cells (SMCs) in vivo $[170,171]$. Even though it is a complicated system and our knowledge of wound healing physiology remains limited, several release systems have already been successfully established [172-176].

Research into "master switch" upstream activators such as HIF1a (hypoxia inducible transcription factor 1 a) that induces provascular signaling cascade represents a new research direction in the growth factor delivery field $[3,5,177]$. HIF-1 is a heterodimeric transcription factor composed of two subunits, HIF-1 $\alpha$ and HIF- $1 \beta$ that are constitutively expressed in most cell types [90,178,179]. Under standard conditions, HIF-1a protein is rapidly degraded by ubiquitinproteasome system. Hypoxic environment on the other hand stabilizes HIF- $1 \alpha$ and consecutively activates the transcription of multiple proangiogenic proteins such as VEGF, SDF-1 and MCP-1, angiopoietins and erythropoietin, which recruit both CD14+ EPCs and CD34+ EPCs from the bone marrow into the circulation, towards the site of hypoxia $[25,64,180-182]$. In contrast with the strategy that aims to carefully bioengineere an environment with pro-vascularization properties, this approach has the potential to induce native regeneration process in vivo.

\section{The Co-cultures of EPCs with Supportive Cells}

In spite of several successes, most studies have demonstrated that the dynamic multistep cascade of angiogenic stimulation in the cellular niche required for vessel regeneration cannot be achieved by addition of one, or multiple angiogenic factors [183-185]. Co-cultures offer a perspective new tool in tissue engineering that has the potential to lead to qualitative and quantitative progress in seeding of the artificial scaffolds and construction of vascular grafts [149,186,187]. As was recently shown, a co-cultivation of different cellular subtypes is able to induce a microenvironment that mimics the cellular niche during the vascularization process. The angiogenic potential of several hematopoietic, mesenchymal and endothelial cell populations has been studied in the context of vessel repair. This mechanism has the potential to regulate vessel repair by paracrine signaling in a coordinated sequence of signaling events. Different cell populations effect distinct phases of vessel regeneration and therefore a diverse population for vascularization is imperative.

The co-culture of early- and late-outgrowth EPCs demonstrated the importance of angiogenic stimulation during vascularization process. Both cell populations secrete multiple cytokines after proangiogenic stimulation, including HGF, insulin-like growth factor 1 (IGF1), FGF and VEGF [188-190]. Their interaction synergistically increases the secretion of pro-angiogenic mediators and supports the differentiation process. Co-cultivation of $\mathrm{CD} 14+$ and $\mathrm{CD} 34+$ cells isolated from peripheral blood was able to create an endothelial layer on 3D scaffold more effectively than CD34+ cells alone [188,190,191]. Although this mechanism increases the endothelial differentiation in vivo as well as in vitro, the effectiveness of the system remains low due to the immature structure of the cultured EC networks. Despite this fact CD14+ or eEPCs are an important contributing factor in the process of vascular regeneration [192].

Recently mesenchymal and endothelial cell co-cultures have been studied to describe the influence of paracrine signaling between cell populations throughout the vasculogenic process. It was shown, that in endothelial-mesechymal co-cultures. Mesenchymal stem cells (MSCs) acquire pericyte phenotype and promote generation of vasculatory network [193-195]. Examination of the MSCs isolated from four

\begin{tabular}{|c|c|c|c|c|c|c|c|}
\hline & Biomaterials & Cells & Long-term pat. & Model & Dimensions & CT & References \\
\hline 2006 & Self-assembly & ECs & 5-8 weeks & maccaques & large-diameter & CT & {$[71]$} \\
\hline 2010 & PGA/PCLL & BM-MNCs & 5,8 years & clinical t. & large-diameter & CT & {$[103,145]$} \\
\hline 2010 & PLA, fibrin & SMCs, ECs, fibroblasts & 6 months & sheep & small-diameter & - & {$[118]$} \\
\hline 2011 & Decellularised art. & SMC and ECs & 4 months & sheep & small-diameter & - & {$[146]$} \\
\hline 2011 & Polyester/collagen & SMCs and ECs & 8 weeks & pig & small-diameter & - & {$[147]$} \\
\hline 2011 & Self-assembly/PGA & ECs & 5-8 weeks & baboons & small-diameter & CT & [131] \\
\hline
\end{tabular}

Table 3: Biomaterials, cell cultures and research models used for preclinical studies in recent years. (Abbreviations: CT - currently ongoing clinical trials, PGA - polyglycolic acid, PCLL - a copolymer of polylactic acid and caprolactone, PLA - polylactic acid.)

\begin{tabular}{|l|l|l|l|}
\hline Growth/signaling f. & Molecular type & Function & References \\
\hline VEGF & Cytokine & Initiator of vessel remodeling and repair \\
\hline bFGF & Heparin-binding protein & Initiates proliferation of EC and SMCs & [72,157,158] \\
\hline HGF & Mitogen & Stimulates growth of ECs & [72,159] \\
\hline PDGF & Mitogen & Recruits SMCs, promotes maturation of the blood vessel & [160] \\
\hline Angiopoietin-1 & Growth factor & Promotes blood vessel maturation, regulates homeostasis & [163] \\
\hline
\end{tabular}

Table 4: Angiogenic growth factors involved in vasculogenesis with a brief description of their essential roles in the process. The signaling factors are arranged in chronological order according to their function. 
distinct tissues demonstrated that this ability is shared among MSCs. In the native tissues pericytes reside in close proximity to ECs. They encompass blood microvessels, and coproduce a basement membrane with ECs demonstrating that pericyte-endothelial interaction plays a key role in basement membrane formation, remodeling and maintenance [196-199]. Furthermore, pericytes have been shown to be critical regulators of vascular development, maturation, remodeling and maintenance of homeostasis by production of angiogenic stimulants including transforming growth factor $\beta$ (TGF $\beta$ ), PDGF and angiopoietin-1 [200-203]. Moreover several models ofpericyteendothelial co-cultures showed best results in direct cell-cell contact co-cultures $[195,204]$. It was shown that pericytes are also present around an engineered blood vessel and are essential for de novovessel formation $[197,205]$.

A 3D microvascular model of co-culture of endothelial cells and various other cell populations including lung fibroblasts, cancer cells and pericytes, investigated the effect of cell populations during critical phases of vascularization. Interestingly it showed that lung fibroblast-produced chemotactic gradient was required for both vasculogenesis and angiogenesis [206]. Without fibroblast co-culture Human Umbilical Vein Endothelial Cells (HUVECs) were not able to form intra-connected networks. Later in the process MSCs co-culture created a well intra-connected network. However, in accordance with in vivo studies this network was non-perfusable which suggests an essential unknown paracrine variable in the process.

Even though, to date, a perfusable $3 \mathrm{D}$ vascular system has not been created, mounting evidence shows that the synergistic effect of paracrine signaling of multiple cell populations has the potential to establish a working model. As we indicated stem cell populations used for vascularization show significant plasticity, and can undergo the differentiation process or Trans-differentiate depending on the microenvironment and presence of other cells.

\section{Conclusion}

Several experimental avenues have been taken for the engineering of functional blood vessels in vivo. Currently, many of these approaches are in the phase of clinical trials. Some have encountered encouraging results, mostly in engineering of large-diameter vascular grafts. However, modern tissue engineering is still not able to restore the function of small diameter arteries. Nonetheless, all of these approaches have solidly established proof of the principle that it is possible to engineer a transplantable blood vessel, functional and durable in vivo. Yet none of the techniques has received any widespread application.

In this review, we summarized the tissue engineering approaches that are currently under investigation. We have focused mainly on the various cell populations involved in the process of vascular reconstitution. We have documented all the known methodologies for the detection and isolation of distinct EPC populations and gathered information about their interaction with other cell types in co-cultures and in in vitrovessel engineering conditions. It has been shown that vascular graft constructs do not require a pure EPC culture. Cocultures possess the advantage of reciprocal angiogenic stimulation and are able to more closely mimic the physiological conditions in the site of injury. The creation of an appropriate microenvironment for EPC differentiation and maturation is a priority for the construction of a vascular graft.

\section{Acknowledgement}

This study was generously supported by the Ministry of Education and CZ.1.07/2.3.00/30.0030 and Grant Agency of the Czech Republic 302/12/ G157 and European Regional Development Fund (FNUSA-ICRC, no CZ.1.05/1.1.00/02.0123)

\section{References}

1. Go AS, Mozaffarian D, Roger VL, Benjamin EJ, Berry JD, et al. (2014) Heart Disease and Stroke Statistics-2014 Update: A Report From the American Heart Association. Circulation 129(3): e28-e292[Pubmed]

2. Fisher MB, Mauck RL (2013) Tissue engineering and regenerative medicine: recent innovations and the transition to translation. Tissue Eng Part $B$ Rev 19(1): 1-13.[Pubmed]

3. Krenning G, van Luyn MJ, Harmsen MC (2009) Endothelial progenitor cellbased neovascularization: implications for therapy. Trends Mol Med 15(4): 180 189.[Pubmed]

4. Li S, Sengupta D, Chien S (2014) Vascular tissue engineering: from in vitro to in situ. Wiley Interdiscip Rev Syst Biol Med 6(1): 61-76.[Pubmed]

5. Risau W (1997) Mechanisms of angiogenesis. Nature 386(6626): 671-674. [Pubmed]

6. Risau W, Flamme I (1995) Vasculogenesis. Annu Rev Cell Dev Biol 11: 73-91 [Pubmed]

7. Asahara T, Murohara T, Sullivan A, Silver M, van der Zee R, et al. (1997) Isolation of putative progenitor endothelial cells for angiogenesis. Science 275(5302): 964-967.[Pubmed]

8. Asahara T, Masuda H, Takahashi T, Kalka C, Pastore C, et al. (1999) Bone marrow origin of endothelial progenitor cells responsible for postnatal vasculogenesis in physiological and pathological neovascularization. Circ Res 85(3): 221-228.[Pubmed]

9. Péault B, Rudnicki M, Torrente Y, Cossu G, Tremblay JP, et al. (2007) Stem and progenitor cells in skeletal muscle development, maintenance, and therapy. Mol Ther 15(5): 867-877.[Pubmed]

10. Zuk PA, Zhu M, Ashjian P, De Ugarte DA, Huang JI, et al. (2002) Human adipose tissue is a source of multipotent stem cells. Mol Biol Cell 13(12): 4279 4295.[Pubmed]

11. Ballas CB, Zielske SP, Gerson SL (2002) Adult bone marrow stem cells for cell and gene therapies: implications for greater use. J Cell Biochem Suppl 38: 20-28.[Pubmed]

12. Chao H, Hirschi KK (2010) Hemato-vascular origins of endothelial progenitor cells? Microvasc Res 79(3): 169-173.[Pubmed]

13. Gimble JM, Katz AJ, Bunnell BA (2007) Adipose-derived stem cells for regenerative medicine. Circ Res 100(9): 1249-1260.[Pubmed]

14. Jiang Y, Jahagirdar BN, Reinhardt RL, Schwartz RE, Keene CD, et al. (2002) Pluripotency of mesenchymal stem cells derived from adult marrow. Nature 418(6893): 41-49.[Pubmed]

15. Minasi MG, Riminucci M, De Angelis L, Borello U, Berarducci B, et al. (2002) The meso-angioblast: a multipotent, self-renewing cell that originates from the dorsal aorta and differentiates into most mesodermal tissues. Development 129(11): 2773-2783.[Pubmed]

16. Barry FP, Murphy JM (2004) Mesenchymal stem cells: clinical applications and biological characterization. Int J Biochem Cell Biol 36(4): 568-584.[Pubmed]

17. Kalka C, Masuda H, Takahashi T, Kalka-Moll WM, Silver M, et al. (2000) Transplantation of ex vivo expanded endothelial progenitor cells for therapeutic neovascularization. Proc Natl Acad Sci U S A 97(7): 3422-3427.[Pubmed]

18. Masuda H, Kalka C, Asahara T (2000) Endothelial progenitor cells for regeneration. Hum Cell 13(4): 153-160.[Pubmed]

19. Kuliszewski MA, Kobulnik J, Lindner JR, Stewart DJ, Leong-Poi H (2011) Vascular gene transfer of SDF-1 promotes endothelial progenitor cell engraftment and enhances angiogenesis in ischemic muscle. Mol Ther 19(5): 895-902.[Pubmed]

20. Formiga FR, Pelacho B, Garbayo E, Abizanda G, Gavira JJ, et al. (2010) Sustained release of VEGF through PLGA microparticles improves vasculogenesis and tissue remodeling in an acute myocardial ischemiareperfusion model. J Control Release 147(1): 30-37.[Pubmed] 
Citation: Salingova B, Madarasova M, Stejskal S, Tesarova L, Simara P, et al. (2014) From Endothelial Progenitor Cells to Tissue Engineering: How Far have we Come? J Stem Cell Res Ther 4: 185. doi:10.4172/2157-7633.1000185

Page 7 of 11

21. Dean EW, Udelsman B, Breuer CK (2012) Current advances in the translation of vascular tissue engineering to the treatment of pediatric congenital heart disease. Yale J Biol Med 85(2): 229-238.[Pubmed]

22. Zhang S, An Q, Li Q, Huang J, Chen X, et al. (2014) Therapeutic benefit of bone marrow-derived endothelial progenitor cell transplantation after experimental aneurysm embolization with coil in rats. PLoS One 9(2): e90069.[Pubmed]

23. L'Heureux N, McAllister TN, de la Fuente LM (2007) Tissue-engineered blood vessel for adult arterial revascularization. N Engl J Med 357(14): 1451-1453. [Pubmed]

24. Medina RJ, O'Neill CL, Humphreys MW, Gardiner TA, Stitt AW (2010) Outgrowth endothelial cells: characterization and their potential for reversing ischemic retinopathy. Invest Ophthalmol Vis Sci 51(11): 5906-5913.[Pubmed]

25. Yamaguchi J Kusano KF, Masuo O, Kawamoto A, Silver M, et al. (2003) Stromal cell-derived factor-1 effects on ex vivo expanded endothelial progenitor cell recruitment for ischemic neovascularization. Circulation 107(9): 13221328.[Pubmed]

26. Wang XX, Zhang FR, Shang YP, Zhu JH, Xie XD, et al. (2007) Transplantation of autologous endothelial progenitor cells may be beneficial in patients with idiopathic pulmonary arterial hypertension: a pilot randomized controlled trial. J Am Coll Cardiol 49 (14): 1566-1571. [Pubmed]

27. Liang C, Feng H, Deng BQ, Li ZF, Huang QH, et al. (2014) Decreased levels and function of circulating endothelial progenitor cells in unruptured intracranial saccular aneurysm patients. Neurol Sci 35(1): 23-28.[Pubmed]

28. Hill JM, Zalos G, Halcox JP, Schenke WH, Waclawiw MA, et al. (2003) Circulating endothelial progenitor cells, vascular function, and cardiovascular risk. N Engl J Med 348(7): 593-600.[Pubmed]

29. Bajpai VK, Andreadis ST (2012) Stem cell sources for vascular tissue engineering and regeneration. Tissue Eng Part B Rev 18(5): 405-425.[Pubmed]

30. Urbich C, Dimmeler S (2004) Endothelial progenitor cells functional characterization. Trends Cardiovasc Med 14(8): 318-322.[Pubmed]

31. Fadini GP, Baesso I, Albiero M, Sartore S, Agostini C, et al. (2008) Technical notes on endothelial progenitor cells: ways to escape from the knowledge plateau. Atherosclerosis 197(2): 496-503.[Pubmed]

32. Hur J, Yoon CH, Kim HS, Choi JH, Kang HJ, et al. (2004) Characterization of two types of endothelial progenitor cells and their different contributions to neovasculogenesis. Arterioscler Thromb Vasc Biol 24(2): 288-293.[Pubmed]

33. Quirici N, Soligo D, Caneva L, Servida F, Bossolasco P, et al. (2001) Differentiation and expansion of endothelial cells from human bone marrow CD133(+) cells. Br J Haematol 115(1): 186-194.[Pubmed]

34. Medina RJ, O'Neill CL, Sweeney M, Guduric-Fuchs J, Gardiner TA, et al (2010) Molecular analysis of endothelial progenitor cell (EPC) subtypes reveals two distinct cell populations with different identities. BMC Med Genomics 3: 18.[Pubmed]

35. Pelosi E, Valtieri M, Coppola S, Botta R, Gabbianelli M, et al. (2002) Identification of the hemangioblast in postnatal life. Blood 100(9): 3203-3208.[Pubmed]

36. Zuk PA, Zhu M, Mizuno H, Huang J, Futrell JW, et al. (2001) Multilineage cells from human adipose tissue: implications for cell-based therapies. Tissue Eng 7(2): 211-228.[Pubmed]

37. Miranville A, Heeschen C, Sengenès C, Curat CA, Busse R, et al. (2004) Improvement of postnatal neovascularization by human adipose tissue-derived stem cells. Circulation 110(3): 349-355.[Pubmed]

38. Xue S, Zhang HT, Zhang P, Luo J, Chen ZZ, et al. (2010) Functional endothelial progenitor cells derived from adipose tissue show beneficial effect on cell therapy of traumatic brain injury. Neurosci Lett 473(3): 186-191.[Pubmed]

39. Hu Y, Zhang Z, Torsney E, Afzal AR, Davison F, et al. (2004) Abundant progenitor cells in the adventitia contribute to atherosclerosis of vein grafts in ApoE-deficient mice. J Clin Invest 113(9): 1258-1265.[Pubmed]

40. Zengin E, Chalajour F, Gehling UM, Ito WD, Treede H, et al. (2006) Vascular wall resident progenitor cells: a source for postnatal vasculogenesis. Development 133(8): 1543-1551. [Pubmed]

41. Peichev M, Naiyer AJ, Pereira D, Zhu Z, Lane WJ, et al. (2000) Expression of VEGFR-2 and AC133 by circulating human CD34(+) cells identifies a population of functional endothelial precursors. Blood 95(3): 952-958.[Pubmed]

42. Cheng SM, Chang SJ, Tsai TN, Wu CH, Lin WS, et al. (2013) Differentia expression of distinct surface markers in early endothelial progenitor cells and monocyte-derived macrophages. Gene Expr 16(1): 15-24.[Pubmed]

43. Cheng CC, Chang SJ, Chueh YN, Huang TS, Huang PH, et al. (2013) Distinct angiogenesis roles and surface markers of early and late endothelial progenito cells revealed by functional group analyses. BMC Genomics 14: 182.[Pubmed]

44. Hager G, Holnthoner W, Wolbank S, Husa AM, Godthardt K, et al. (2013) Three specific antigens to isolate endothelial progenitor cells from human liposuction material. Cytotherapy 15(11): 1426-1435.[Pubmed]

45. De Francesco F, Tirino V, Desiderio V, Ferraro G, D'Andrea F, et al. (2009) Human CD34/CD90 ASCs are capable of growing as sphere clusters, producing high levels of VEGF and forming capillaries. PLoS One 4(8): e6537.[Pubmed]

46. Rzhaninova AA, Kulikov AV, Spirova IA, Kirienko EE, Volkov AV, et al. (2010) Preparation and characterization of culture of CD146+ cells from human adipose tissue. Bull Exp Biol Med 149(1): 113-118.[Pubmed]

47. Richardson MR, Yoder MC (2011) Endothelial progenitor cells: quo vadis? J Mol Cell Cardiol 50(2): 266-272.[Pubmed]

48. Eggermann J, Kliche S, Jarmy G, Hoffmann K, Mayr-Beyrle U, et al. (2003) Endothelial progenitor cell culture and differentiation in vitro: a methodological comparison using human umbilical cord blood. Cardiovasc Res 58(2): 478-486. [Pubmed]

49. Gehling UM, Ergün S, Schumacher U, Wagener C, Pantel K, et al. (2000) In vitro differentiation of endothelial cells from AC133-positive progenitor cells. Blood 95(10): 3106-3112.[Pubmed]

50. Reyes M, Dudek A, Jahagirdar B, Koodie L, Marker PH, et al. (2002) Origin of endothelial progenitors in human postnatal bone marrow. J Clin Invest 109(3) 337-346.[Pubmed]

51. Mobarrez F, Antoniewicz L, Bosson JA, Kuhl J, Pisetsky DS, et al. (2014) The effects of smoking on levels of endothelial progenitor cells and microparticles in the blood of healthy volunteers. PLoS One 9(2): e90314.[Pubmed]

52. Graziani F, Leone AM, Basile E, Cialdella P, Tritarelli A, et al. (2014) Endothelial Progenitor Cells in Morbid Obesity. Circ J.[Pubmed]

53. Volaklis KA, Tokmakidis SP, Halle M (2013) Acute and chronic effects of exercise on circulating endothelial progenitor cells in healthy and diseased patients. Clin Res Cardiol 102(4): 249-257.[Pubmed]

54. Lamirault G, Susen S, Forest V, Hemont C, Parini A, et al. (2013) Difference in mobilization of progenitor cells after myocardial infarction in smoking versus non-smoking patients: insights from the BONAMI trial. Stem Cell Res Ther 4(6) 152.[Pubmed]

55. Tilling L, Chowienczyk $P$, Clapp B (2009) Progenitors in motion: mechanisms of mobilization of endothelial progenitor cells. Br J Clin Pharmacol 68(4): 484492.[Pubmed]

56. Shintani S, Murohara T, Ikeda H, Ueno T, Honma T, et al. (2001) Mobilization of endothelial progenitor cells in patients with acute myocardial infarction Circulation 103(23): 2776-2779.[Pubmed]

57. Shimizu N, Nakaseko C, Jiang M, Nishii K, Yokote K, et al. (2014) G-CSF induces the release of the soluble form of LR11, a regulator of myeloid cell mobilization in bone marrow. Ann Hematol.[Pubmed]

58. Cho HJ, Kim HS, Lee MM, Kim DH, Yang HJ, et al. (2003) Mobilized endothelial progenitor cells by granulocyte-macrophage colony-stimulating factor accelerate reendothelialization and reduce vascular inflammation after intravascular radiation. Circulation 108 (23): 2918-2925. [Pubmed]

59. Zhou J, Cheng M, Liao YH, Hu Y, Wu M, et al. (2013) Rosuvastatin enhances angiogenesis via eNOS-dependent mobilization of endothelial progenitor cells. PLoS One 8(5): e63126.[Pubmed]

60. Han X, Yang N, Cui Y, Xu Y, Dang G, et al. (2012) Simvastatin mobilizes bone marrow stromal cells migrating to injured areas and promotes functional recovery after spinal cord injury in the rat. Neurosci Lett 521(2): 136-141. [Pubmed]

61. Kalka C, Masuda H, Takahashi T, Gordon R, Tepper O, et al. (2000) Vascular endothelial growth factor(165) gene transfer augments circulating endothelia progenitor cells in human subjects. Circ Res 86(12): 1198-1202.[Pubmed]

62. Kalka C, Tehrani H, Laudenberg B, Vale PR, Isner JM, et al. (2000) VEGF gene transfer mobilizes endothelial progenitor cells in patients with inoperable coronary disease. Ann Thorac Surg 70(3): 829-834.[Pubmed] 
63. Schweigerer L, Neufeld G, Friedman J, Abraham JA, Fiddes JC, et al. (1987) Capillary endothelial cells express basic fibroblast growth factor, a mitogen that promotes their own growth. Nature 325(6101): 257-259.[Pubmed]

64. Heeschen C, Aicher A, Lehmann R, Fichtlscherer S, Vasa M, et al. (2003) Erythropoietin is a potent physiologic stimulus for endothelial progenitor cell mobilization. Blood 102(4): 1340-1346.[Pubmed]

65. Hoh BL, Hosaka K, Downes DP, Nowicki KW, Wilmer EN, et al. (2014) Stroma cell-derived factor-1 promoted angiogenesis and inflammatory cell infiltration in aneurysm walls. J Neurosurg 120(1): 73-86.[Pubmed]

66. Wang LL, Chen D, Lee J, Gu X, Alaaeddine G, et al. (2014) Mobilization of endogenous bone marrow derived endothelial progenitor cells and therapeutic potential of parathyroid hormone after ischemic stroke in mice. PLoS One 9(2): e87284.[Pubmed]

67. Liao JK (2004) Statin therapy: having the good without the bad. Hypertension 43(6): 1171-1172.[Pubmed]

68. Vasa M, Fichtlscherer S, Adler K, Aicher A, Martin H, et al. (2001) Increase in circulating endothelial progenitor cells by statin therapy in patients with stable coronary artery disease. Circulation 103(24): 2885-2890.[Pubmed]

69. Dimmeler S, Aicher A, Vasa M, Mildner-Rihm C, Adler K, et al. (2001) HMGCoA reductase inhibitors (statins) increase endothelial progenitor cells via the PI 3-kinase/Akt pathway. J Clin Invest 108(3): 391-397.[Pubmed]

70. L'Heureux N, Dusserre N, Konig G, Victor B, Keire P, et al. (2006) Human tissue-engineered blood vessels for adult arterial revascularization. Nat Med 12(3): 361-365.[Pubmed]

71. Liles WC, Broxmeyer HE, Rodger E, Wood B, Hübel K, et al. (2003) Mobilization of hematopoietic progenitor cells in healthy volunteers by AMD3100, a CXCR4 antagonist. Blood 102(8): 2728-2730.[Pubmed]

72. Li J, Zhang YP, Kirsner RS (2003) Angiogenesis in wound repair: angiogenic growth factors and the extracellular matrix. Microsc Res Tech 60(1): 107-114. [Pubmed]

73. Mao L, Huang M, Chen SC, Li YN, Xia YP, et al. (2014) Endogenous Endothelia Progenitor Cells Participate in Neovascularization via CXCR4/SDF-1 axis and Improve Outcome After Stroke. CNS Neurosci Ther.[Pubmed]

74. Vasa M, Fichtlscherer S, Aicher A, Adler K, Urbich C, et al. (2001) Number and migratory activity of circulating endothelial progenitor cells inversely correlate with risk factors for coronary artery disease. Circ Res 89(1): E1-7.[Pubmed]

75. Cesari F, Marcucci R, Gori AM, Burgisser C, Francini S, et al. (2014) Adherence to lifestyle modifications after a cardiac rehabilitation program and endothelial progenitor cells. A six-month follow-up study. Thromb Haemost 112(1). [Pubmed]

76. Kao YH, Chiu WC, Hsu MI, Chen YJ (2013) Endothelial Progenitor Cell Dysfunction in Polycystic Ovary Syndrome: Implications for The Genesis of Cardiovascular Diseases. Int J Fertil Steril 6(4): 208-213.[Pubmed]

77. Sambataro M, Seganfreddo E, Canal F, Furlan A, Del Pup L, et al. (2014) Prognostic significance of circulating and endothelial progenitor cell markers in type 2 diabetic foot. Int J Vasc Med 2014: 589412.[Pubmed]

78. Berezin AE, Kremzer AA (2014) Circulating endothelial progenitor cells as markers for severity of ischemic chronic heart failure. J Card Fail.[Pubmed]

79. Martí-Fàbregas J, Crespo J, Delgado-Mederos R, Martínez-Ramírez S, Peña E, et al. (2013) Endothelial progenitor cells in acute ischemic stroke. Brain Behav 3(6): 649-655.[Pubmed]

80. Liao YF, Feng Y, Chen LL, Zeng TS, Yu F, et al. (2014) Coronary heart disease risk equivalence in diabetes and arterial diseases characterized by endothelia function and endothelial progenitor cell. J Diabetes Complications 28(2): 214 218.[Pubmed]

81. Wadajkar AS, Menon JU, Kadapure T, Tran RT, Yang J, et al. (2013) Design and Application of Magnetic-based Theranostic Nanoparticle Systems. Recent Pat Biomed Eng 6(1): 47-57.[Pubmed]

82. Wadajkar AS, Santimano S, Tang L, Nguyen KT (2014) Magnetic-based multilayer microparticles for endothelial progenitor cell isolation, enrichment, and detachment. Biomaterials 35(2): 654-663.[Pubmed]

83. Fadini GP, Losordo D, Dimmeler S (2012) Critical reevaluation of endothelial progenitor cell phenotypes for therapeutic and diagnostic use. Circ Res 110(4): 624-637.[Pubmed]
84. Yoder MC, Mead LE, Prater D, Krier TR, Mroueh KN, et al. (2007) Redefining endothelial progenitor cells via clonal analysis and hematopoietic stem/ progenitor cell principals. Blood 109(5): 1801-1809.[Pubmed]

85. Van Craenenbroeck EM, Conraads VM, Van Bockstaele DR, Haine SE Vermeulen K, et al. (2008) Quantification of circulating endothelial progenito cells: a methodological comparison of six flow cytometric approaches. J Immunol Methods 332(1-2): 31-40.[Pubmed]

86. Fina L, Molgaard HV, Robertson D, Bradley NJ, Monaghan P, et al. (1990) Expression of the CD34 gene in vascular endothelial cells. Blood 75(12): $2417-$ 2426.[Pubmed]

87. Yin AH, Miraglia S, Zanjani ED, Almeida-Porada G, Ogawa M, et al. (1997) AC133, a novel marker for human hematopoietic stem and progenitor cells Blood 90(12): 5002-5012.[Pubmed]

88. Xiao Q, Ye S, Oberhollenzer F, Mayr A, Jahangiri M, et al. (2008) SDF1 gene variation is associated with circulating SDF1alpha level and endothelia progenitor cell number: the Bruneck Study. PLoS One 3(12): e4061.[Pubmed]

89. Nagano M, Yamashita T, Hamada H, Ohneda K, Kimura K, et al. (2007) Identification of functional endothelial progenitor cells suitable for the treatment of ischemic tissue using human umbilical cord blood. Blood 110(1): 151-160. [Pubmed]

90. Werner N, Junk S, Laufs U, Link A, Walenta K, et al. (2003) Intravenous transfusion of endothelial progenitor cells reduces neointima formation after vascular injury. Circ Res 93(2): e17-24.[Pubmed]

91. Zhang W, Zhang G, Jin H, Hu R (2006) Characteristics of bone marrow-derived endothelial progenitor cells in aged mice. Biochem Biophys Res Commun 348(3): 1018-1023.[Pubmed]

92. Pompilio G, Capogrossi MC, Pesce M, Alamanni F, DiCampli C, et al (2009) Endothelial progenitor cells and cardiovascular homeostasis: clinical implications. Int J Cardiol 131(2): 156-167.[Pubmed]

93. Rehman J, Li J, Orschell CM, March KL (2003) Peripheral blood "endothelial progenitor cells" are derived from monocyte/macrophages and secrete angiogenic growth factors. Circulation 107(8): 1164-1169.[Pubmed]

94. Rohde E, Malischnik C, Thaler D, Maierhofer T, Linkesch W, et al. (2006) Blood monocytes mimic endothelial progenitor cells. Stem Cells 24(2): 357367.[Pubmed]

95. Kim SY, Park SY, Kim JM, Kim JW, Kim MY, et al. (2005) Differentiation of endothelial cells from human umbilical cord blood AC133-CD14+ cells. Ann Hematol 84(7): 417-422.[Pubmed]

96. Povsic TJ, Goldschmidt-Clermont PJ (2008) Endothelial progenitor cells: markers of vascular reparative capacity. Ther Adv Cardiovasc Dis 2(3): 199 213.[Pubmed]

97. Werner N, Kosiol S, Schiegl T, Ahlers P, Walenta K, et al. (2005) Circulating endothelial progenitor cells and cardiovascular outcomes. $\mathrm{N}$ Engl J Med 353(10): 999-1007.[Pubmed]

98. Werner N, Nickenig G (2006) Influence of cardiovascular risk factors on endothelial progenitor cells: limitations for therapy? Arterioscler Thromb Vasc Biol 26(2): 257-266.[Pubmed]

99. Povsic TJ, Zavodni KL, Vainorius E, Kherani JF, Goldschmidt-Clermont PJ, et al. (2009) Common endothelial progenitor cell assays identify discrete endothelial progenitor cell populations. Am Heart J 157(2): 335-344.[Pubmed]

100. Watt SM,Butler LH, Tavian M, Bühring HJ, Rappold I, et al. (2000) Functionally defined CD164 epitopes are expressed on CD34(+) cells throughout ontogeny but display distinct distribution patterns in adult hematopoietic and nonhematopoietic tissues. Blood 95 (10): 3113-3124.[Pubmed]

101. Tura O, Skinner EM, Barclay GR, Samuel K, Gallagher RC, et al. (2013) Late outgrowth endothelial cells resemble mature endothelial cells and are not derived from bone marrow. Stem Cells 31(2): 338-348.[Pubmed]

102. Gulati R, Jevremovic D, Peterson TE, Chatterjee S, Shah V, et al. (2003) Diverse origin and function of cells with endothelial phenotype obtained from adult human blood. Circ Res 93(11): 1023-1025.[Pubmed]

103. Hibino N, McGillicuddy E, Matsumura G, Ichihara Y, Naito Y, et al. (2010) Late-term results of tissue-engineered vascular grafts in humans. J Thorac Cardiovasc Surg 139(2): 431-436, 436.[Pubmed]

104. Sapsford RN, Oakley GD, Talbot S (1981) Early and late patency of expanded polytetrafluoroethylene vascular grafts in aorta-coronary bypass. J Thorac Cardiovasc Surg 81(6): 860-864.[Pubmed] 
Citation: Salingova B, Madarasova M, Stejskal S, Tesarova L, Simara P, et al. (2014) From Endothelial Progenitor Cells to Tissue Engineering: How Far have we Come? J Stem Cell Res Ther 4: 185. doi:10.4172/2157-7633.1000185

105. Veith FJ, Gupta SK, Ascer E, White-Flores S, Samson RH, et al. (1986) Six-year prospective multicenter randomized comparison of autologous saphenous vein and expanded polytetrafluoroethylene grafts in infrainguinal arterial reconstructions. J Vasc Surg 3 (1): 104-114. [Pubmed]

106. Brennan MP, Dardik A, Hibino N, Roh JD, Nelson GN, et al. (2008) Tissueengineered vascular grafts demonstrate evidence of growth and development when implanted in a juvenile animal model. Ann Surg 248(3): 370-377. [Pubmed]

107. Herring MB, Dilley R, Jersild RA Jr, Boxer L, Gardner A, et al. (1979) Seeding arterial prostheses with vascular endothelium. The nature of the lining. Ann Surg 190(1): 84-90.[Pubmed]

108. Herring M, Gardner A, Glover J (1978) A single-staged technique for seeding vascular grafts with autogenous endothelium. Surgery 84(4): 498-504. [Pubmed]

109. Seifalian AM, Salacinski HJ, Tiwari A, Edwards A, Bowald S, et al. (2003) In vivo biostability of a poly(carbonate-urea)urethane graft. Biomaterials 24(14): 2549-2557.[Pubmed]

110. Weinberg CB, Bell E (1986) A blood vessel model constructed from collagen and cultured vascular cells. Science 231(4736): 397-400.[Pubmed]

111. Niklason LE, Gao J, Abbott WM, Hirschi KK, Houser S, et al. (1999) Functional arteries grown in vitro. Science 284(5413): 489-493.[Pubmed]

112. Huynh T, Abraham G, Murray J, Brockbank K, Hagen PO, et al. (1999) Remodeling of an acellular collagen graft into a physiologically responsive neovessel. Nat Biotechnol 17(11): 1083-1086.[Pubmed]

113. Nugent HM, Edelman ER (2003) Tissue engineering therapy for cardiovascular disease. Circ Res 92(10): 1068-1078.[Pubmed]

114. Gui L, Zhao L, Spencer RW, Burghouwt A, Taylor MS, et al. (2011) Development of novel biodegradable polymer scaffolds for vascular tissue engineering. Tissue Eng Part A 17(9-10): 1191-1200.[Pubmed]

115. Quint C, Arief M, Muto A, Dardik A, Niklason LE (2012) Allogeneic human tissue-engineered blood vessel. J Vasc Surg 55(3): 790-798.[Pubmed]

116. Quint C, Kondo Y, Manson RJ, Lawson JH, Dardik A, et al. (2011) Decellularized tissue-engineered blood vessel as an arterial conduit. Proc Nat Acad Sci U S A 108(22): 9214-9219.[Pubmed]

117. Duttenhoefer F, Lara de Freitas R, Meury T, Loibl M, Benneker LM, et al. (2013) 3D scaffolds co-seeded with human endothelial progenitor and mesenchymal stem cells: evidence of prevascularisation within 7 days. Eur Cell Mater 26: 49-64.[Pubmed]

118. Koch S, Flanagan TC, Sachweh JS, Tanios F, Schnoering H, et al. (2010) Fibrin-polylactide-based tissue-engineered vascular graft in the arterial circulation. Biomaterials 31(17): 4731-4739.[Pubmed]

119. Pankajakshan D, Agrawal DK (2010) Scaffolds in tissue engineering of blood vessels. Can J Physiol Pharmacol 88(9): 855-873.[Pubmed]

120. Jiang B, Akar B, Waller TM, Larson JC, Appel AA, et al. (2014) Design of a composite biomaterial system for tissue engineering applications. Acta Biomater 10(3): 1177-1186.[Pubmed]

121. He W, Yong T, Teo WE, Ma Z, Ramakrishna S (2005) Fabrication and endothelialization of collagen-blended biodegradable polymer nanofibers: potential vascular graft for blood vessel tissue engineering. Tissue Eng 11(910): 1574-1588.[Pubmed]

122. Hashi CK, Derugin N, Janairo RR, Lee R, Schultz D, et al. (2010) Antithrombogenic modification of small-diameter microfibrous vascular grafts. Arterioscler Thromb Vasc Biol 30(8): 1621-1627.[Pubmed]

123. Shin'oka T, Imai Y, Ikada $Y$ (2001) Transplantation of a tissue-engineered pulmonary artery. N Engl J Med 344(7): 532-533.[Pubmed]

124. L'Heureux N, Pâquet S, Labbé R, Germain L, Auger FA (1998) A completely biological tissue-engineered human blood vessel. FASEB J 12(1): 47-56. [Pubmed]

125. McAllister TN, Maruszewski M, Garrido SA, Wystrychowski W, Dusserre N, et al. (2009) Effectiveness of haemodialysis access with an autologous tissueengineered vascular graft: a multicentre cohort study. Lancet 373(9673): 1440-1446.[Pubmed]

126. Torikai K, Ichikawa H, Hirakawa K, Matsumiya G, Kuratani T, et al. (2008) A self-renewing, tissue-engineered vascular graft for arterial reconstruction. $J$ Thorac Cardiovasc Surg 136(1): 37-45, 45.[Pubmed]
127. Laflamme K, Roberge CJ, Pouliot S, D'Orléans-Juste P, Auger FA et al. (2006) Tissue-engineered human vascular media produced in vitro by the self-assembly approach present functional properties similar to those of their native blood vessels. Tissue Eng 12 (8): 2275-2281.[Pubmed]

128. Peck M, Gebhart D, Dusserre N, McAllister TN, L'Heureux N (2012) The evolution of vascular tissue engineering and current state of the art. Cells Tissues Organs 195(1-2): 144-158.[Pubmed]

129. Gauvin R, Guillemette M, Galbraith T, Bourget JM, Larouche D, et al. (2011) Mechanical properties of tissue-engineered vascular constructs produced using arterial or venous cells. Tissue Eng Part A 17(15-16): 2049-2059. [Pubmed]

130. Gauvin R, Ahsan T, Larouche D, Lévesque P, Dubé J, et al. (2010) A nove single-step self-assembly approach for the fabrication of tissue-engineered vascular constructs. Tissue Eng Part A 16(5): 1737-1747.[Pubmed]

131.Dahl SL, Kypson AP, Lawson JH, Blum JL, Strader JT, et al. (2011) Readily available tissue-engineered vascular grafts. Sci Transl Med 3(68): 68ra9. [Pubmed]

132.Dahl SL, Blum JL, Niklason LE (2011) Bioengineered vascular grafts: can we make them off-the-shelf? Trends Cardiovasc Med 21(3): 83-89.[Pubmed]

133. Cleary MA, Geiger E, Grady C, Best C, Naito Y, et al. (2012) Vascular tissue engineering: the next generation. Trends Mol Med 18(7): 394-404.[Pubmed]

134. Shudo Y, Cohen JE, Macarthur JW, Atluri P, Hsiao PF, et al. (2013) Spatially oriented, temporally sequential smooth muscle cell-endothelial progenitor cell bi-level cell sheet neovascularizes ischemic myocardium. Circulation 128 (11 Suppl 1): S59-68.[Pubmed]

135. Wang C, Cen L, Yin S, Liu Q, Liu W, et al. (2010) A small diameter elastic blood vessel wall prepared under pulsatile conditions from polyglycolic acid mesh and smooth muscle cells differentiated from adipose-derived stem cells Biomaterials 31 (4): 621-630. [Pubmed]

136. Hu J, Xie C, Ma H, Yang B, Ma PX, et al. (2012) Construction of vascula tissues with macro-porous nano-fibrous scaffolds and smooth muscle cells enriched from differentiated embryonic stem cells. PLoS One 7(4): e35580. [Pubmed]

137. Kirkpatrick CJ, Krump-Konvalinkova V, Unger RE, Bittinger F, Otto M, et al. (2002) Tissue response and biomaterial integration: the efficacy of in vitro methods. Biomol Eng 19(2-6): 211-217.[Pubmed]

138. Klinkert P, Post PN, Breslau PJ, van Bockel JH (2004) Saphenous vein versus PTFE for above-knee femoropopliteal bypass. A review of the literature. Eur J Vasc Endovasc Surg 27(4): 357-362.[Pubmed]

139. Weitz JI, Byrne J, Clagett GP, Farkouh ME, Porter JM, et al. (1996) Diagnosis and treatment of chronic arterial insufficiency of the lower extremities: a critical review. Circulation 94(11): 3026-3049.[Pubmed]

140.Loh SA, Howell BS, Rockman CB, Cayne NS, Adelman MA et al (2013) Mid- and long-term results of the treatment of infrainguinal arterial occlusive disease with precuffed expanded polytetrafluoroethylene grafts compared with vein grafts. Ann Vasc Surg 27(2): 208-217.[Pubmed]

141.Pereira CE, Albers M, Romiti M, Brochado-Neto FC, Pereira CA (2006) Meta-analysis of femoropopliteal bypass grafts for lower extremity arterial insufficiency. J Vasc Surg 44(3): 510-517.[Pubmed]

142.de Mel A, Jell G, Stevens MM, Seifalian AM (2008) Biofunctionalization of biomaterials for accelerated in situ endothelialization: a review. Biomacromolecules 9(11): 2969-2979.[Pubmed]

143. Jordan SW, Chaikof EL (2007) Novel thromboresistant materials. J Vasc Surg 45 Suppl A: A104-115.[Pubmed]

144.Zilla P, Bezuidenhout D, Human P (2007) Prosthetic vascular grafts: wrong models, wrong questions and no healing. Biomaterials 28(34): 5009-5027. [Pubmed]

145. Shin'oka T, Matsumura G, Hibino N, Naito Y, Watanabe M, et al. (2005) Midterm clinical result of tissue-engineered vascular autografts seeded with autologous bone marrow cells. J Thorac Cardiovasc Surg 129(6): 1330-1338. [Pubmed]

146. Neff LP, Tillman BW, Yazdani SK, Machingal MA, Yoo JJ, et al. (2011) Vascular smooth muscle enhances functionality of tissue-engineered blood vessels in vivo. J Vasc Surg 53(2): 426-434.[Pubmed]

147.Baguneid M, de Mel A, Yildirimer L, Fuller BJ, Hamilton G, et al. (2011) In 
vivo study of a model tissue-engineered small-diameter vascular bypass graft. Biotechnol Appl Biochem 58(1): 14-24.[Pubmed]

148. Geevarghese A, Herman IM (2014) Pericyte-endothelial crosstalk: implications and opportunities for advanced cellular therapies. Transl Res.[Pubmed]

149. Kirkpartrick CJ, Fuchs S, Unger RE (2011) Co-culture systems for vascularization--learning from nature. Adv Drug Deliv Rev 63(4-5): 291-299. [Pubmed]

150.Bauters C, Asahara T, Zheng LP, Takeshita S, Bunting S, et al. (1994) Physiological assessment of augmented vascularity induced by VEGF in ischemic rabbit hindlimb. Am J Physiol 267(4 pt 2): H1263-1271.[Pubmed]

151. Freedman SB, Isner JM (2002) Therapeutic angiogenesis for coronary artery disease. Ann Intern Med 136(1): 54-71.[Pubmed]

152. Takeshita S, Pu LQ, Stein LA, Sniderman AD, Bunting S, et al. (1994) Intramuscular administration of vascular endothelial growth factor induces dose-dependent collateral artery augmentation in a rabbit model of chronic limb ischemia. Circulation 90 (5 Pt 2): II228-234. [Pubmed]

153. Takeshita S, Zheng LP, Brogi E, Kearney M, Pu LQ, et al. (1994) Therapeutic angiogenesis. A single intraarterial bolus of vascular endothelial growth factor augments revascularization in a rabbit ischemic hind limb model. J Clin Invest 93(2): 662-670.[Pubmed]

154. Rosengart TK, Lee LY, Patel SR, Kligfield PD, Okin PM, et al. (1999) Six-month assessment of a phase I trial of angiogenic gene therapy for the treatment of coronary artery disease using direct intramyocardial administration of an adenovirus vector expressing the VEGF121 cDNA. Ann Surg 230 (4): 466470; discussion 470-462. [Pubmed]

155. Schumacher B, Pecher P, von Specht BU, Stegmann T (1998) Induction of neoangiogenesis in ischemic myocardium by human growth factors: first clinical results of a new treatment of coronary heart disease. Circulation 97(7): 645-650.[Pubmed]

156. Simons M, Annex BH, Laham RJ, Kleiman N, Henry T, et al. (2002) Pharmacological treatment of coronary artery disease with recombinant fibroblast growth factor-2: double-blind, randomized, controlled clinical trial. Circulation 105(7): 788-793. [Pubmed]

157.Bauer SM, Bauer RJ, Velazquez OC (2005) Angiogenesis, vasculogenesis, and induction of healing in chronic wounds. Vasc Endovascular Surg 39(4): 293-306.[Pubmed]

158. Huang YC, Kaigler D, Rice KG, Krebsbach PH, Mooney DJ (2005) Combined angiogenic and osteogenic factor delivery enhances bone marrow stromal cell-driven bone regeneration. J Bone Miner Res 20(5): 848-857.[Pubmed]

159. Lin H, Chen B, Sun W, Zhao W, Zhao Y, et al. (2006) The effect of collagentargeting platelet-derived growth factor on cellularization and vascularization of collagen scaffolds. Biomaterials 27(33): 5708-5714.[Pubmed]

160. Zhao W, Han Q, Lin H, Gao Y, Sun W, et al. (2008) Improved neovascularization and wound repair by targeting human basic fibroblast growth factor (bFGF) to fibrin. J Mol Med (Berl) 86(10): 1127-1138.[Pubmed]

161. Andrae J, Gallini R, Betsholtz C (2008) Role of platelet-derived growth factors in physiology and medicine. Genes Dev 22(10): 1276-1312.[Pubmed]

162. Elçin YM, Dixit V, Gitnick G (2001) Extensive in vivo angiogenesis following controlled release of human vascular endothelial cell growth factor: implications for tissue engineering and wound healing. Artif Organs 25 (7): 558-565. [Pubmed]

163. Fiedler U, Augustin HG (2006) Angiopoietins: a link between angiogenesis and inflammation. Trends Immunol 27(12): 552-558.[Pubmed]

164. Suarez S, Grover GN, Braden RL, Christman KL, Almutairi A (2013) Tunable protein release from acetalated dextran microparticles: a platform for delivery of protein therapeutics to the heart post-MI. Biomacromolecules 14(11): 3927 3935.[Pubmed]

165. Liu Y, Sun L, Huan Y, Zhao H, Deng J (2006) Effects of basic fibroblast growth factor microspheres on angiogenesis in ischemic myocardium and cardiac function: analysis with dobutamine cardiovascular magnetic resonance tagging. Eur J Cardiothorac Surg 30 (1): 103-107. [Pubmed]

166. Yamamoto T, Suto N, Okubo T, Mikuniya A, Hanada H, et al. (2001) Intramyocardial delivery of basic fibroblast growth factor-impregnated gelatin hydrogel microspheres enhances collateral circulation to infarcted canine myocardium. Jpn Circ J 65 (5): 439-444. [Pubmed]
167. Sakakibara Y, Tambara K, Sakaguchi G, Lu F, Yamamoto M, et al. (2003) Toward surgical angiogenesis using slow-released basic fibroblast growth factor. Eur J Cardiothorac Surg 24(1): 105-111.[Pubmed]

168. Simón-Yarza T, Tamayo E, Benavides C, Lana H, Formiga FR, et al. (2013) Functional benefits of PLGA particulates carrying VEGF and CoQ10 in an animal of myocardial ischemia. Int J Pharm 454(2): 784-790.[Pubmed]

169. Simón-Yarza T, Formiga FR, Tamayo E, Pelacho B, Prosper F, et al. (2013) PEGylated-PLGA microparticles containing VEGF for long term drug delivery. Int J Pharm 440(1): 13-18.[Pubmed]

170.Roy R, Zhang B, Moses MA (2006) Making the cut: protease-mediated regulation of angiogenesis. Exp Cell Res 312(5): 608-622.[Pubmed]

171.Zisch AH, Lutolf MP, Hubbell JA (2003) Biopolymeric delivery matrices for angiogenic growth factors. Cardiovasc Pathol 12(6): 295-310.[Pubmed]

172. Ehrbar M, Djonov VG, Schnell C, Tschanz SA, Martiny-Baron G, et al. (2004) Cell-demanded liberation of VEGF121 from fibrin implants induces local and controlled blood vessel growth. Circ Res 94(8): 1124-1132.[Pubmed]

173. Seliktar D, Zisch AH, Lutolf MP, Wrana JL, Hubbell JA (2004) MMP-2 sensitive, VEGF-bearing bioactive hydrogels for promotion of vascular healing. J Biomed Mater Res A 68(4): 704-716.[Pubmed]

174.Zisch AH, Lutolf MP, Ehrbar M, Raeber GP, Rizzi SC, et al. (2003) Celldemanded release of VEGF from synthetic, biointeractive cell ingrowth matrices for vascularized tissue growth. FASEB J 17(15): 2260-2262.[Pubmed]

175. Han F, Jia X, Dai D, Yang X, Zhao J, et al. (2013) Performance of a multilayered small-diameter vascular scaffold dual-loaded with VEGF and PDGF. Biomaterials 34(30): 7302-7313.[Pubmed]

176. Ehrbar M, Zeisberger SM, Raeber GP, Hubbell JA, Schnell C, et al. (2008) The role of actively released fibrin-conjugated VEGF for VEGF receptor 2 gene activation and the enhancement of angiogenesis. Biomaterials 29(11): 17201729.[Pubmed]

177.Distler JH, Hirth A, Kurowska-Stolarska M, Gay RE, Gay S, et al. (2003) Angiogenic and angiostatic factors in the molecular control of angiogenesis. $Q$ J Nucl Med 47(3): 149-161.[Pubmed]

178. Wiener CM, Booth G, Semenza GL (1996) In vivo expression of mRNAs encoding hypoxia-inducible factor 1. Biochem Biophys Res Commun 225(2) 485-488.[Pubmed]

179. Huang LE, Gu J, Schau M, Bunn HF (1998) Regulation of hypoxia-inducible factor 1alpha is mediated by an O2-dependent degradation domain via the ubiquitin-proteasome pathway. Proc Natl Acad Sci U S A 95(14): 7987-7992. [Pubmed]

180. Grunewald M, Avraham I, Dor Y, Bachar-Lustig E, Itin A, et al. (2006) VEGFinduced adult neovascularization: recruitment, retention, and role of accessory cells. Cell 124(1): 175-189.[Pubmed]

181. Morimoto $H$, Takahashi $M$, Shiba $Y$, Izawa A, Ise $H$, et al. (2007) Bone marrow-derived CXCR4+ cells mobilized by macrophage colony-stimulating factor participate in the reduction of infarct area and improvement of cardiac remodeling after myocardial infarction in mice. Am J Pathol 171 (3): 755-766. [Pubmed]

182. Ramakrishnan S, Anand V, Roy S (2014) Vascular endothelial growth factor signaling in hypoxia and inflammation. J Neuroimmune Pharmacol 9(2): 142 160.[Pubmed]

183. Alajati A, Laib AM, Weber H, Boos AM, Bartol A et al. (2008) Spheroid-based engineering of a human vasculature in mice. Nat Methods 5(5): 439-445. [Pubmed]

184. Newman AC, Nakatsu MN, Chou W, Gershon PD, Hughes CC (2011) The requirement for fibroblasts in angiogenesis: fibroblast-derived matrix proteins are essential for endothelial cell lumen formation. Mol Biol Cell 22(20): 3791 3800.[Pubmed]

185. Voog J, Jones DL (2010) Stem cells and the niche: a dynamic duo. Cell Stem Cell 6(2): 103-115.[Pubmed]

186. Hellström M, Gerhardt H, Kalén M, Li X, Eriksson U, et al. (2001) Lack of pericytes leads to endothelial hyperplasia and abnormal vascular morphogenesis. J Cell Biol 153(3): 543-553.[Pubmed]

187. Sieveking DP, Buckle A, Celermajer DS, Ng MK (2008) Strikingly different angiogenic properties of endothelial progenitor cell subpopulations: insights from a novel human angiogenesis assay. J Am Coll Cardiol 51(6): 660-668. [Pubmed] 
Citation: Salingova B, Madarasova M, Stejskal S, Tesarova L, Simara P, et al. (2014) From Endothelial Progenitor Cells to Tissue Engineering: How Far have we Come? J Stem Cell Res Ther 4: 185. doi:10.4172/2157-7633.1000185

Page 11 of 11

188. Awad O, Dedkov El, Jiao C, Bloomer S, Tomanek RJ, et al. (2006) Differential healing activities of CD34+ and CD14+ endothelial cell progenitors. Arterioscler Thromb Vasc Biol 26(4): 758-764.[Pubmed]

189. Majka M1, Janowska-Wieczorek A, Ratajczak J, Ehrenman K, Pietrzkowski Z, et al. (2001) Numerous growth factors, cytokines, and chemokines are secreted by human $\mathrm{CD} 34(+)$ cells, myeloblasts, erythroblasts, and megakaryoblasts and regulate normal hematopoiesis in an autocrine/paracrine manner. Blood 97 (10): 3075-3085. [Pubmed]

190. Yoon CH, Hur J, Park KW, Kim JH, Lee CS, et al. (2005) Synergistic neovascularization by mixed transplantation of early endothelial progenitor cells and late outgrowth endothelial cells: the role of angiogenic cytokines and matrix metalloproteinases. Circulation 112 (11): 1618-1627. [Pubmed]

191. Krenning G, van der Strate BW, Schipper M, van Seijen XJ, Fernandes BC et al. (2009) CD34+ cells augment endothelial cell differentiation of CD14+ endothelial progenitor cells in vitro. J Cell Mol Med 13(8B): 2521-2533. [Pubmed]

192. Bhattacharya V, Shi Q, Ishida A Sauvage LR, Hammond WP, et al. (2000) Administration of granulocyte colony-stimulating factor enhances endothelialization and microvessel formation in small-caliber synthetic vascular grafts. J Vasc Surg 32(1): 116-123.[Pubmed]

193. Lin RZ, Moreno-Luna R, Zhou B, Pu WT, Melero-Martin JM (2012) Equal modulation of endothelial cell function by four distinct tissue-specific mesenchymal stem cells. Angiogenesis 15(3): 443-455.[Pubmed]

194. Pedersen TO, Blois AL, Xue Y, Xing Z, Sun Y, et al. (2014) Mesenchymal stem cells induce endothelial cell quiescence and promote capillary formation. Stem Cell Res Ther 5(1): 23.[Pubmed]

195.Loibl M, Binder A, Herrmann M, Duttenhoefer F, Richards RG, et al. (2014) Direct Cell-Cell Contact between Mesenchymal Stem Cells and Endothelial Progenitor Cells Induces a Pericyte-Like Phenotype In Vitro. Biomed Res Int 2014: 395781.[Pubmed]

196. Armulik A, Genové G, Betsholtz C (2011) Pericytes: developmental, physiological, and pathological perspectives, problems, and promises. Dev Cell 21(2): 193-215.[Pubmed]

197. Dar A, Domev H, Ben-Yosef O, Tzukerman M, Zeevi-Levin N, et al. (2012) Multipotent vasculogenic pericytes from human pluripotent stem cells promote recovery of murine ischemic limb. Circulation 125(1): 87-99.[Pubmed]

198. Corselli M, Chen CW, Sun B, Yap S, Rubin JP, et al. (2012) The tunica adventitia of human arteries and veins as a source of mesenchymal stem cells. Stem Cells Dev 21(8): 1299-1308.[Pubmed]

199. Ding L, Saunders TL, Enikolopov G, Morrison SJ (2012) Endothelial and perivascular cells maintain haematopoietic stem cells. Nature 481(7382): 457462.[Pubmed]

200.Berger M, Bergers G, Arnold B, Hämmerling GJ, Ganss R (2005) Regulator of $\mathrm{G}$-protein signaling-5 induction in pericytes coincides with active vesse remodeling during neovascularization. Blood 105(3): 1094-1101.[Pubmed]

201.Bergers G, Song S (2005) The role of pericytes in blood-vessel formation and maintenance. Neuro Oncol 7(4): 452-464.[Pubmed]

202. Gaengel K, Genové G, Armulik A, Betsholtz C (2009) Endothelial-mural cell signaling in vascular development and angiogenesis. Arterioscler Thromb Vasc Biol 29(5): 630-638.[Pubmed]

203. Carrion B, Kong YP, Kaigler D, Putnam AJ (2013) Bone marrow-derived mesenchymal stem cells enhance angiogenesis via their $\hat{I} \pm 6 \hat{i}^{2} 1$ integrin receptor. Exp Cell Res 319(19): 2964-2976.[Pubmed]

204. Lavender MD, Pang Z, Wallace CS, Niklason LE, Truskey GA (2005) A system for the direct co-culture of endothelium on smooth muscle cells. Biomaterials 26(22): 4642-4653.[Pubmed]

205. He W, Nieponice A, Soletti L, Hong Y, Gharaibeh B, et al. (2010) Pericytebased human tissue engineered vascular grafts. Biomaterials 31(32): 82358244.[Pubmed]

206. Kim S, Lee H, Chung M, Jeon NL (2013) Engineering of functional, perfusable 3D microvascular networks on a chip. Lab Chip 13(8): 1489-1500.[Pubmed] 